\title{
Factors determinant of bank capital buffer: empirical study on islamic rural banking in Indonesia
}

\author{
Sutrisno \\ Universitas Islam Indonesia, Yogjakarta, Indonesia
}

\begin{abstract}
Capital is a very important aspect of the banking industry as it will be used to cover the losses suffered by the bank. Financial Services Authority set a minimum limit of the bank's capital adequacy ratio of $8 \%$. This study aims to determine the size of capital buffer. There are several factors believed to determine the amount of capital buffer, such as the return on assets (ROA), non-performing financing (NPF), financing to deposit ratio (FDR), the net profit margin (NPM), and the ratio of operating expenses to operating income (OEIR). The study population was 164 BPRS in Indonesia and samples taken randomly of 55 SRB with quarterly data for two years (2015-2016). It used multiple regression analysis with the help of programming SPSS version 17.0. The results showed NPF, FDR, and NPM variables significantly affects capital buffer while ROA and OEIR are not significant.
\end{abstract}

Keywords: capital buffer, non-performing financing, financing to deposit ratio, net profit margin

\section{BACK GROUND}

The banking institution is a fundamental part of the operation of the economic system especially their role as financial intermediaries (Roulet et al. 2012). In this role, banking institution mobilizes funds from surplus units to then be distributed to the party fund deficit. Eliskovski (2013) agreed that the bank occupies an important position in the modern financial sector. Bank funds mostly come from the public, so that the bank operates should be subject to regulation, supervised and controlled by the government through the financial services authority (FSA). Capital is one element regulated by government banking to maintain their solvability.

In order to create a healthy and stable financial system, financial regulators enforce regulations related to bank capital adequacy. (Bayuseno \& Chabahib (2014) revealed that the regulatory capital adequacy was adopted by the Basel Committee on Banking Supervision which BASEL I, II and III. In the agreement, Basel is arranged the amount of capital adequacy ratio (CAR) of $8 \%$ at the minimum. BASEL III also requires that banking institutions have capital buffers in order to deal with the risk.
The capital buffer is essential for banks to deal with risks and economy shocks at any time. The higher capital buffer shows that the bank is getting stronger. It is expected that the public increasingly believes to banks on the services. There are several factors that affect the capital buffers, among others, the level of profitability. The higher the profit of enterprises provide opportunities to increase capital buffer, as gains in part as retained earnings and will be accumulated on the capital itself. Belem \& Gartner (2013) and Haryanto (2015) said that the profitability affects capital buffers. Similarly, the benefit ratio as measured by net profit margin (NIM) also has a positive effect on the capital buffer as found by Mili et al. (2016).

Non-Performing Financing (NPF) leads to the decreasing profit because the cost will be higher. These losses should be covered by capital so that it requires a higher capital buffer. Bayuseno \& Chabahib (2014) found a positive effect of the credit risk as measured by NPL to capital buffers. Liquidity, as measured by the financing to deposit ratio (FDR), indicates the higher financing provided, meaning that the higher FDR can cause the higher the bank income that will eventually add the bank capital. 
According to Zhu \& Liping (2016), LDR positively affects the risk operating capital buffer.

\section{LITERATURE REVIEW}

\subsection{Capital Buffer}

Capital for the banks has a very important role in supporting the operations of the bank in order to run smoothly (Haryanto 2015). Bank capital serves as a backup if one bank suffered losses. In accordance with the rules of the Bank for International Settlements (BIS), capital is measured by capital adequacy ratio (CAR) of $8 \%$ at a minimum. However, a bank is also required to provide additional capital above the CAR so-called capital buffer. Thus the capital buffer is the difference between CAR provided by banks with a minimum CAR. If a bank has a capital adequacy ratio at $15 \%$, meaning that the bank possessed a capital buffer of $7 \%$. A bank with a large buffer capital underlines the bank's ability to bear the risk. However, if the capital buffer is too higher, the bank is less efficient in utilizing the capital base.

\subsection{Profitability and capital buffer}

The company's goal is to earn profits that partly used to pay dividends and partly as retained earnings. Retained earnings will increase the capital that leads to higher capital buffers. Belem \& Gartner (2013) and Haryanto (2015) found a positive and significant influence between profitability and capital buffers. $\mathrm{H}_{1}$ : Profitability (ROA) has a positive effect on capital buffer

\subsection{Non performing Financing and capital buffer}

One of the risks of banking is in the collection of installment payment failure resulting in high financing problems. Non-performing financing (NPF) is a measure of where the higher financing risk NPF show bank failures in the operation because the NPF reduces profits and could even cause harm. If the bank suffered a loss then the required additional capital to cover losses through a high capital buffer is needed. Eliskovski (2013) in Macedonia and Zhu and Liping (2016) in China found a positive effect of credit risk on the capital buffer.

$\mathrm{H}_{2}$ : Non performing financing (NPF) has a positive effect on capital buffer

\subsection{Financing to deposit ratio and capital buffer}

Financing to Deposit Ratio (FDR) shows the amount of financing granted compared with public funds. The higher FDR means higher financing provided.
IRB main revenue comes from financing, so the higher the financing will increase the revenue that will ultimately increase profits. Thus, the higher the FDR would increase the capital buffer. Belem \& Gartner (2013) and Haryanto (2015) found the risk of liquidity, as measured by a positive effect of LDR on the capital buffer.

$\mathrm{H}_{3}$ : Financing to deposit ratio (FDR) has a positive effect on capital buffer

\subsection{Net profit margin and capital buffers}

Quality of bank management that relates to net profit margin affects the size of capital buffers. NIM is used to measure the ability of management resulted in net interest income divided by earning assets. NIM or NPM reflects the cost of financial intermediation, thus the higher NIM leads to higher NPM capital buffer provided. Mili et al. (2014) and Raharjo et al. (2014) discovered NIM has a positive effect on capital adequacy.

$\mathrm{H}_{4}$ : Net prpfit margin (FDR)has a positive effect on capital buffer

\subsection{Operating Expense to income ratio and capital buffer}

One important aspect of banking is efficiency in order to increase the level of bank profits. In the tight banking industry competition, the advantage of efficiency is highly recommended. Efficiency is measured by operating expense to income ratio (OEIR), meaning that the higher this ratio the more inefficient the bank's operations. The more efficient the bank will be able to increase the profits that could eventually increase the capital buffer as revealed by Raharjo (2014) who found a positive influence between OEIR and the buffer stock.

$\mathrm{H}_{5}$ : Operating expense to income ratio (OEIR) has a positive effect on capital buffer

\section{RESEARCH METHOD}

\subsection{Data and Sample}

The population in this study was rural Islamic banks in Indonesia as many as 164 banks and samples taken as many as 55 BPRS by purposive sampling method. An observation period was two years (2015 - 2016) with quarterly data. 


\subsection{Variables and measurement}

In the study, there is one dependent variable and five independent variables. Here are the measurements of each variable:

Table 1: Variables Measurement

\begin{tabular}{ll}
\hline Variable & Measurement \\
\hline Banking perfomance & EAT/Total Assets \\
Financing risk & $\begin{array}{l}\text { Non-perform Financing//Total } \\
\text { fnancing } \\
\text { Total financing/third party fund } \\
\text { Liquidity risk } \\
\text { Capital risk }\end{array}$ \\
$\begin{array}{l}\text { Total equity/risk-weighted assets } \\
\text { Operating risk }\end{array}$ & $\begin{array}{l}\text { Financing Income/Net financing } \\
\text { Operating expense/operating income }\end{array}$ \\
\hline
\end{tabular}

\section{RESULT AND DISCUSSION}

\subsection{Descriptive Statistics}

There were 55 Islamic Rural Banks taken as the sample by using purposive sampling technique with quarterly data for two years (2015-2016), which obtained 440 data. The descriptive statistical results from data processing using SPSS version 17.0 are as follows:

Table 2: Descriptive Statistics

\begin{tabular}{llllll}
\hline & $\mathrm{N}$ & Minimum & Maximum & Mean & $\begin{array}{l}\text { Std. De- } \\
\text { viation }\end{array}$ \\
\hline ROA & 440 & -13.75 & 202.00 & 3.0047 & 10.1106 \\
NPF & 440 & 0.00 & 31.84 & 7.8882 & 5.6884 \\
CAR & 440 & 7.25 & 95.94 & 24.0968 & 16.1474 \\
FDR & 440 & 0.77 & 384.01 & 96.0936 & 38.2304 \\
NPM & 440 & 0.01 & 0.88 & 0.1581 & 0.1042 \\
OEOI & 440 & 0.21 & 1.99 & 0.5541 & 0.1856 \\
\hline
\end{tabular}

The variable of Islamic Rural Banks Performance measured by ROA indicated a minimum value of $13.75 \%$ and the maximum value of $220.00 \%$ with an average of $3.00 \%$. It means that although there are several Islamic Rural Banks suffered losses but there are also several Islamic Rural Banks which generate a very high profit, but the average shows a relatively low profit. For capital (CAR), there are several banks which are still at $7.25 \%$, below the minimum requirement of $8 \%$, but there is a bank which is at $95.94 \%$ with a CAR average of $24.10 \%$. Liquidity (FDR) has a minimum value of $0.77 \%$, and a maximum value of $384.01 \%$, with an average of $96.09 \%$. Management risk as measured by NPM is still low as it is indicated by the minimum value of $0.01 \%$ and maximum value $0.88 \%$ with an average of $0.16 \%$. While the operational risk (OEOI) is very good since it has an average of $55.41 \%$.

\subsection{Result of Hypothesis testing}

The table below shows the results of hypothesis testing by using multiple regression:

Table 3: Hypothesis Result

\begin{tabular}{llll}
\hline Model & Coeficient & $\mathrm{t}$ & sig. \\
\hline (Constant) & 0.000 & 1.043 & 0.297 \\
ROA & 0.082 & 1.262 & 0.207 \\
NPF & 0.169 & 3.401 & 0.001 \\
FDR & 0.200 & 5.111 & 0.000 \\
NPM & 0.227 & 5.861 & 0.000 \\
BOPO & 0.112 & 1.559 & 0.120 \\
\hline
\end{tabular}

a. Dependent Variable: BUFF

Based on the table above with a significance level of $5 \%$, it was obtained that the variable of profitability is not significant to the capital buffer. The result shows a rise in profitability that is not able to boost capital buffers. This is possible because the performance of PBRS as measured by ROA is not good, with an average of only $0.63 \%$. These results are consistent with the findings of Noreen et al. (2016), but against Belem \& Gartner (2013), Eliskovski (2013), and Bayuseno \& Chabahib (2014)

Risk financing $\left(\mathrm{NPF}_{\mathrm{t}-1)}\right.$ has a significant and positive impact, so the increase in $\mathrm{NPF}_{\mathrm{t}-1}$ leads to an increase capital buffers, meaning that banks will have to raise capital itself. The study results are consistent with findings Eliskovski (2013), Wang and Ke (2012), and Haryanto (2015).

Bank liquidity (FDR) also has a significant influence and positive impact on capital buffers. This indicates that the increase in FDR would raise corporate profits and ultimately raise the company's capital and increase capital buffers. Belem \& Gartner (2013) and Mili et al. (2014) also found a significant and positive effect between liquidity on the capital buffer.

Net profit margin (NPM) as a measure of efficiency has a significant positive effect, meaning that high NPM will increase capital buffers because more efficient banks will increase the profits which accordingly add to capital buffer. These results are consistent with the findings of Maureen \& Toivanen (2012) and Mili et al. (2014).

Operating risk, as measured by operating expense to income ratio (OEIR) has no significant effect, meaning that changes in OEIR will not affect the value of capital buffers. This is possible because the operating risk is controlled well. Zhu and Chen (2016) also found OEIR has no influence on the capital buffer which contrary to the findings of Belem \& Gartner (2013) and Wang \& Ke (2012). 


\section{CONCLUSION AND RECOMMENDATIONS}

Based on these results, it can be concluded that the hypothesis proven is the risk of financing (NPF), liquidity (FDR) and efficiency (NIM) while profitability variable (ROA) and operating risk (OEIR) are not proven.

The results of this study are not perfect and still need to be developed by further research of adding other variables that affect capital buffers.

\section{REFERENCES}

Belém, V. C. \& Gartner, I. R. 2016. Empirical analysis of Brazilian banks' capital buffers during the period 2001-2011. R. Cont. Fin. - USP 27 (70): 113-124.

Bayuseno, V. \& Chabahib, M. 2014. Analisis Faktor Yang Mempengaruhi Capital Buffer Perbankan Di Indonesia (Studi Pada Bank-Bank Konvensional Go Public Periode 2010-2013). Diponegoro Journal of Management 3(4): 113.

Roulet, C., Distinguin, I. \& Tarazi, A. 2012. Bank Capital Buffer and Liquidity: Evidence from US and European Publicly Traded Banks. 29th International Conference of the French Finance Association (AFFI). Proceedings. Strasbourg (France), May 14-16, 2012

Eliskovski, M,. 2013. The Determinants Of Capital Buffer In The Macedonian Banking Sector. Journal of Contemporary Economic and Business Issues 1(2): 19-33.

Haryanto, S. 2015. Determinan Capital Buffer: Kajian Empirik Industri Perbankan Nasional. Modernisasi 11(2): 108-123

Maurin, L. \& Toivanen, M,. 2012. Risk, Capital Buffer And Bank Lending: A Granular Approach to the Adjustment of Euro Area Banks. Working Paper Series. European Central Bank.

Mili, M,. Sahut, J. M. \& Trimeche, H. 2014. Determinants of the Capital Adequacy Ratio of a Foreign Bank's Subsidiaries: The Role of the Interbank Market and Regulation of Multinational Banks. Working Paper. IPAG Business School. Paris-France.

Noreen, U,. Alamdar, F., \& Tariq, T. 2016. Capital Buffers and Bank Risk: Empirical Study of Adjustment of Pakistani Banks. International Journal of Economics and Financial Issues 6(4): 1798-1806.

Raharjo, P. G,. Hakim, D. B,.. Manurung, A. H., \& Maulana, T. N. A,. 2014. Determinant of Capital Ratio: A Panel Data Analysis On State-Owned Banks In Indonesia. Bulletin of Monetary, Economics and Banking 16(4): 369-385.

Wang, C \& Ke, X. 2012. Determinants of Bank Capital: Evidence from the U.S. Unpublished Master Thesis. Simon Fraser University.

Zhu, C \& Liping, C. 2016. An Empirical Study on the Capital Buffer of Rural Commercial Banks in China. Journal of Finance and Economics 4(3): 97-102. 